\title{
PLANNING AND TRACKING OF A PROJECT IN A CONSTRUCTION INDUSTRY
}

\author{
Vijayendra B V $\mathbf{1}^{\mathbf{1}}$, Shashikumar $\mathrm{A}^{\mathbf{2}}$, G. Narayana ${ }^{3}$ \\ ${ }^{1}$ Post Graduate Student, Department of Civil Department, S.J.C.I.T, Chickballapura, Karnataka, India \\ ${ }^{2}$ Assistant Professor, Department of Civil Department, S.J.C.I.T, Chickballapura, Karnataka, India \\ ${ }^{3}$ Professor \& Head of Department of Civil Engineering, S.J.C.I.T, Chickballapura, Karnataka, India
}

\begin{abstract}
Proper planning and scheduling is very essential in construction to minimize and prevents the delays of construction. considerable amount of time, resources are wasted every year in construction industry due to improper planning and scheduling. With globalization the construction works will be huge and complex planning in such cases large amount of paper work will required. Which can be reduced by the software like MS project by providing proper data to that in proper manner then it will give good result. The warning mechanism should implement in this to alert the organizing team In correct time. The main important in this study is proper plan and schedule with tracking of multy level car parking and analyze what are the present position of the work. The MS project program is being the primary supply in conducting this study. This application might be utilizing to increase a planning and scheduling model for the constructing building task. Despite the fact that the usage of this software between the constructions enterprise remains to be cut back, for that reason with the construction of those documents in the end will give the person some enter about the importance of the primavera.
\end{abstract}

Keywords; Planning, Scheduling, Tracking, Construction Management

\section{INTRODUCTION}

Now a days, in all construction industry is experiencing prolong in completion of the assignment. The trouble arise due to quite a lot of factors, the primary supply is brought on by means of development endeavor which isn't accomplished in step with planning and scheduling efficiently. Ultimately, contractor will want time extension to finish the mission. The prolong crisis is not brought about by using lack of correct care and mistake via the contractor, nevertheless it's ordinarily purpose with the aid of drive fundamental reminiscent of defection in supplying development substances, variation order via patron and the typical catastrophe comparable to wet season.

Essentially it be trained is an exploratory gain knowledge of on implementation of Microsoft assignment in each facet of a task which comprise of Plan and Scheduling stage adopted by using the Monitoring and controlling stage. The next goals are undertaken in this study, specifically

1. To be trained the scheduling procedure utilizing network items (CPM)

2. To gain knowledge of the development sequence of labor for multi storey constructing (WBS)

3. Software of Microsoft assignment program in planning \& scheduling in an effort to S-Curve for physical percentage of the undertaking.
Nowadays, practically each development enterprise in India is experiencing extend problem. The main issue happens from quite a lot of reasons; the broad sources are triggered by the construction undertaking which has been executed no longer consistent with planning and scheduling effectually made up our minds earlier than specific execution of the undertaking. It sounds as if, contractor will require time extension to accomplish the assignment. The Extension of time will receive to the lengthen in obstacle no longer triggered as a result of lack of correct care (incautious, unaware) and mistake via the contractor, nevertheless it's regularly precipitated by way of principal forces equivalent to inconvenience in presenting development substances, version order (VO) by means of customer as a result of the nature disaster akin to wet season. Involving to the extension of time in a challenge existence, it will incur the cost rises to both associates, or customer or contractors.

The extension of time (EOT) given to the contractor does no longer cause inconvenience or error to contractor, if celebration is facing the quandary, accordingly they must be responsible and bare the additional rate due the procrastinations of the issues. As a consequence, the time will stretch, rate will expand and henceforth the quality of the undertaking will degrade. Furthermore, as the development industry end up extra stringent and develop in progress, as a penalties it's is complicated to the venture manager to monitor and manage abortion caused by way of 
ineffectiveness in scheduling and inadequacy of building knowledge. Consequently planning and scheduling have to put into effect satisfactorily and carefully with the motive of accomplish the project effectively within time, and satisfactory required. Furthermore, as the challenge increase in size, the development's movements end up extra adamant. As a sequence, the clash in routine sequence befell because of inefficient planning and scheduling. With a purpose to speed up, it is fundamental to center of attention on every part of development events earlier than establishing its. Planning and scheduling efficiency relies on the methodology used. To attain the objectives of a challenge can be meaningless if the system used shouldn't be correct. As we all know, the mission scheduling is very important in challenge's lifestyles, sadly now not many civil engineer gurus exercises implementation and applications of Microsoft task in building challenge. On different hand part, presently the contractors who used ordinary process (Bar Chart in Microsoft Excel) still lead the best rank compared to the today's.

\section{PROJECT MANAGEMENT}

Mission administration is the system of accomplishing undertaking ambitions (agenda, finances and performance) by means of a set of hobbies that begin and finish at precise elements in time and produce quantifiable and qualifiable deliverables.

Positive venture management is the artwork of bringing collectively the tasks, assets and people imperative to accomplish the industry objectives and targets inside the designated time constraints and inside the monetary allowance. Tasks and packages are linked straight to the strategic objectives and initiatives of the organization supported.

The approach every supervisor follows for the duration of the life of a project is referred to as the challenge administration existence Cycle. A verified methodical existence cycle is indispensable to repeatedly implement and control projects successfully.

Throughout the life cycle of any assignment, established and demonstrated mission administration procedures or quality practices are will have to be initiated. The varieties and extent of methods initiated depend on the character of the project, i.e. Dimension, likelihood of failure and consequences of failure. Robust and mighty leaders follow system to shield all projects.

The task administration Institute (PMI) presents steering for undertaking management in the mission management physique of advantage (PMBOK). Every assignment has a lifestyles cycle, with a opening, a life and an end (outlined with the aid of engaging in the target).

The steps shows typical project life period

- Initiation

- Planning

- Executing

- Monitoring and controlling processes

- Closing

\section{Initiation Processes}

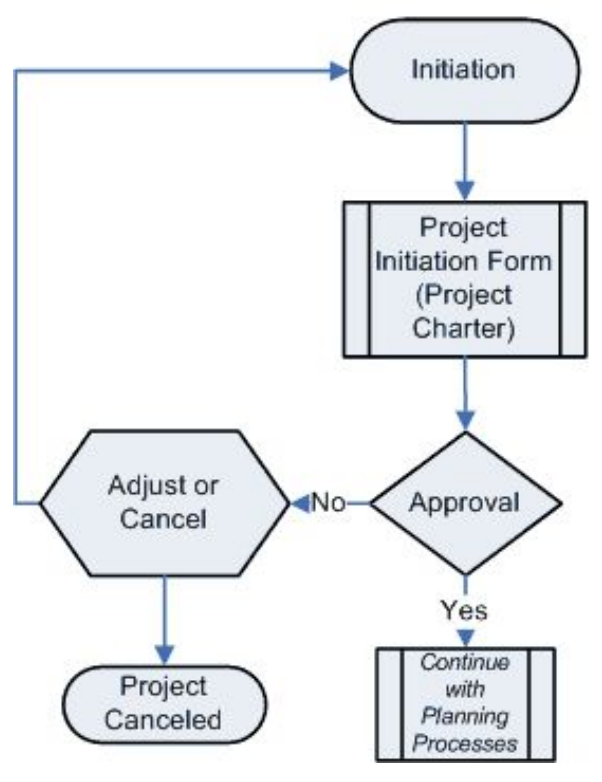

\subsection{Planning}

Planning is the process listing of all activates which comes under that particular constriction. Requirement of substances, manpower, machineries and cash are determined on this section. Estimates of budget and period for the various activities are made. The target planning is to establish the quite a lot of operations are require to be performed for the finishing of the work and to provide a time table or proper sequential relationship between the events, with every undertaking allocated start date and finish date and with the peace of mind that the things critical to do every activity can be on hand when required. The steps required to carry out one of these planning incorporate common sense (planning), timing, analysis and scheduling. Enter for planning comes from the estimating departments, task managers, discipline engineers, foremen, contractors. Planning is the bottom of the entire venture and have to be situated on clearly outlined targets. With suitable planning, ample assets are to be had on the right moment and ample time is allowed for each and every stage in the procedure and the entire various aspect events at suitable times. 


\section{Planning Processes}

\section{Executing Processes}
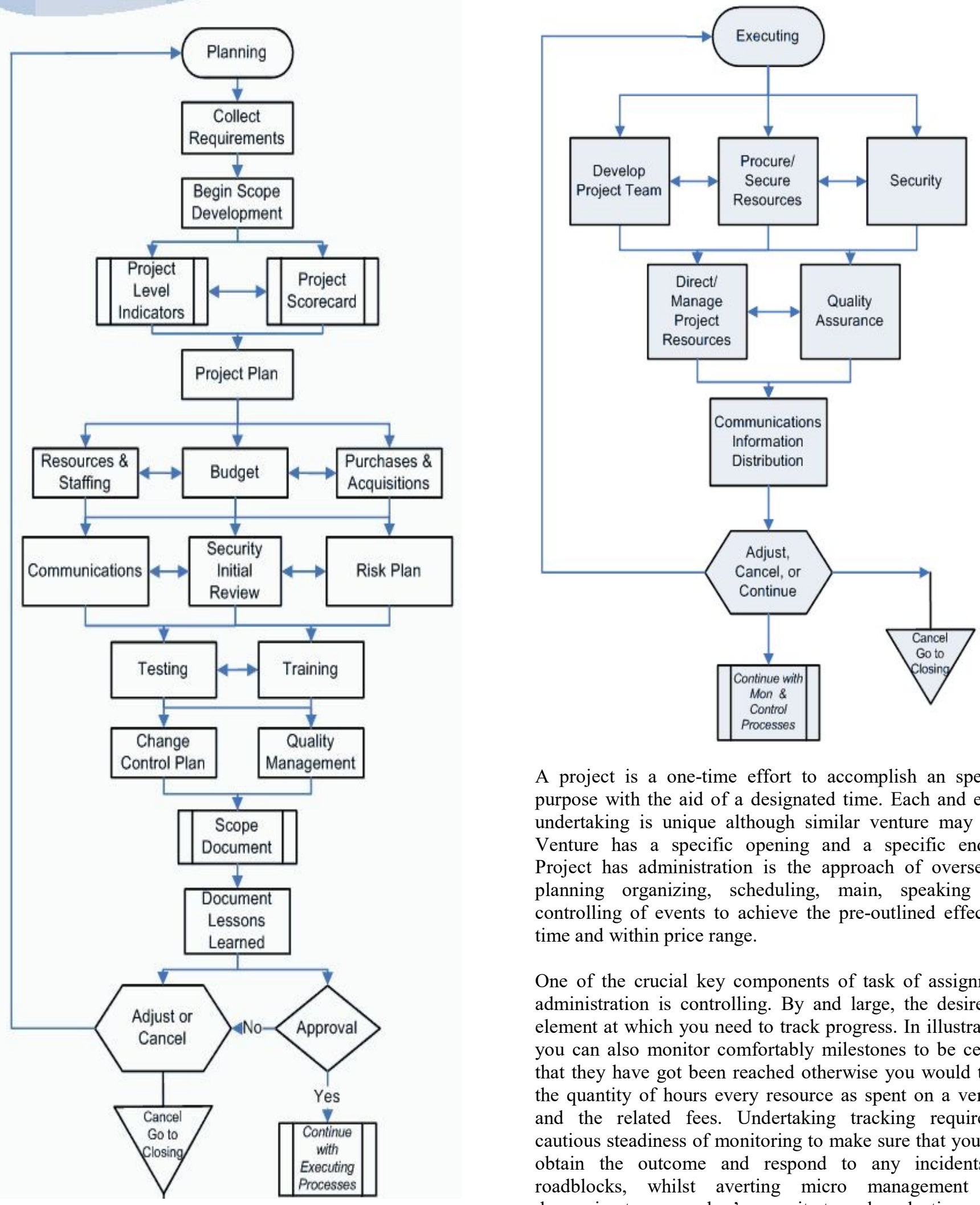

A project is a one-time effort to accomplish an specific purpose with the aid of a designated time. Each and every undertaking is unique although similar venture may exit. Venture has a specific opening and a specific ending. Project has administration is the approach of overseeing planning organizing, scheduling, main, speaking and controlling of events to achieve the pre-outlined effect on time and within price range.

One of the crucial key components of task of assignment administration is controlling. By and large, the desires of element at which you need to track progress. In illustration, you can also monitor comfortably milestones to be certain that they have got been reached otherwise you would track the quantity of hours every resource as spent on a venture and the related fees. Undertaking tracking requires a cautious steadiness of monitoring to make sure that you will obtain the outcome and respond to any incidents or roadblocks, whilst averting micro management and decreasing team member's capacity to make selections. 
Properly tracking exact work and comparing it's towards normal plan is valuable to identify the difference in specific and planned and it enables to adjust incomplete challenge of the plan.

\section{Closing Processes}

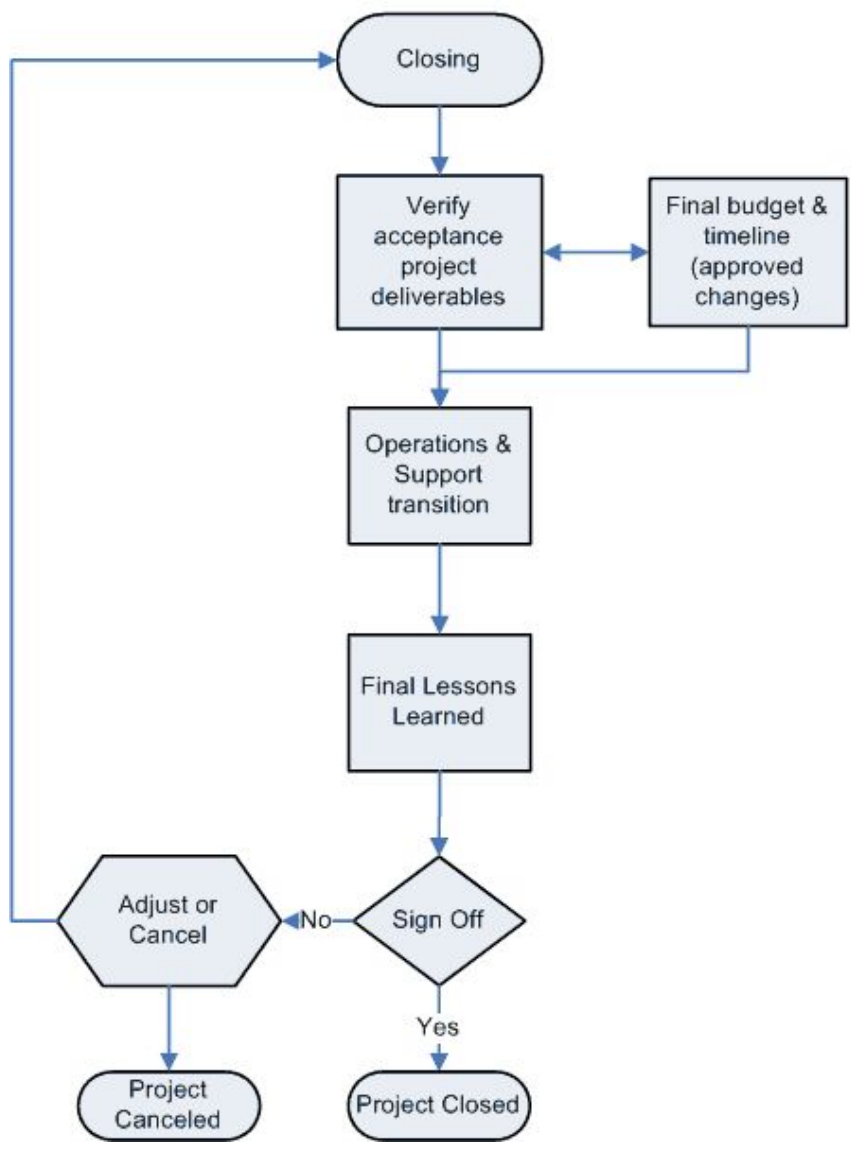

\section{PROJECT PLAN DEVELOPMENT}

Preparing a project execution plan is the first critical step in managing a project. The project execution plan is the manager blue print to achieve project success. It spells out the project manager approach to managing the project scope without any conflict and using effective change management practices it also lays out a project managers tool kit to manage schedule variance, cost variance, quality failures, communication failures, procurement issues and human resource imperatives while effective managing project risks this document and is constantly updated to act as a guide to project execution and achieving project results.

Assumption, constraints and risks are related reviews to arrive and effective alternative to manage the construction process.

The project execution plan covers the following

1) Project Brief - giving details of the project technicalities, site location and site peculiarities and what is required by the client as their stated needs.

2) Project Contact Sheet - listing the key stakeholders, their representatives and their phone and email contacts 
3) Project Scope And Milestones - This lays out the specific scope of the project and the approach of the project manager to achieve this scope of work, as well as listing the main milestones in achieving this goal.

4) Project Design Management - This describes the approach taken by the project manager in ensuring that the design is in line with client requirements and the coordination planned for aligning civil, electrical, plumbing, fire-fighting, landscape, and other works constituting the final building design.

5) Project Organization Chart - This shows the key organizational roles for all stakeholders and the internal command structure of each stakeholder along with their key roles and responsibilities.

6) Project Time Management - This section explains the planned schedule and how the project manager proposes to manage likely deviations from planned execution to achieve the project delivery on time.

7) Project Budget And Cost Control Procedures - This section explains the approach taken by the project team to monitor and control the project cost within the budget allocated to the project including the cost control measures and how changes will be monitored to keep the project cost under control.

8)Risk And Sensitivity Analysis - This section gives a brief idea about the overall risks perceived in the project and updated to reflect new risk perception as the project progresses. The risks are qualified and its impact on time, cost and quality are evaluated. The final plans to mitigate the risks are also laid out here.

9) Project Procurement Management - This section indicates the strategy used by the project to ensure timely procurement of materials and services for executing the project with inputs on how any deviation in procurement plans and the attendant risks in procurement are to be addressed in the project.

10) Project Change Management - This section lists the accepted change control process for the project with details of the authorization levels for each type of change in the project. This lays out clear rules for meeting the project charter while accommodating or rejecting the changes proposed.

11) Project Documentation Management - This section declares the standard documents that will be created for the project and the rules relating to document updates and document sharing.

12) Project Communication Management - This section indicates the communication rules that are to be applied for communication between various stakeholders indicating both what can be communicated directly and what needs to be routed through the PMC.
13) Project Safety Management - This section indicates the safety plan for the project that has been agreed upon by all stakeholders and the mechanism to ensure that safety is well managed to prevent any untoward incidents / accidents during project execution.

14) Project Commissioning And Handling Over - This section defines Virtual Completion of the project and the various measures that will be adopted with tests to be conducted to declare the project ready for handing over to the client.

15) Escalation Matrix - The escalation matrix provides the turnaround times and rules for escalating timely project issues to progressively higher levels of authority for timely solutions to project issues.

16) RACI Matrix- This matrix indicates the person / stakeholder who is responsible for action, stakeholder authorized to approve actions, stakeholder to be consulted for major decisions and the stakeholders who should be kept informed regarding key project actions and decisions.

\section{Man Power Management}

Man power administration is fundamental in construction enterprise. That is in view that:

- Manpower is type of resource, if labors shouldn't be used in time, they are misplaced they usually must be paid for it. However, other resources like money, substances, equipments are usually not misplaced when they don't seem to be utilized in time.

- Man power is an energetic resource where as other assets is passive. Other resources are to be utilized with the aid of manpower. So, if the manpower is utilized in a greater manner different resources can be utilized quite simply and economically.

- Unskilled manpower is to be had in a significant quantity, but skilled manpower just isn't on hand big numbers. Consequently, right management of manpower will help in balancing this quandary. The summary of the manpower necessities is mostly presented in tables and graphs.

Delay is particularly original in building initiatives. Extend can also be prompted by the corporation, the Contractor, and the 0.33 party or the drive majeure that the parties to a contract cannot control. Prolong to completion of a challenge might bring tremendous losses on society as well because the mission fee. It will accrue as a result of interior or external routine of the mission, it can be typical issues or man mistakes. Subsequently it influences on the project compilation time, it could be managed by way of taking preliminary precautions in proper method. 


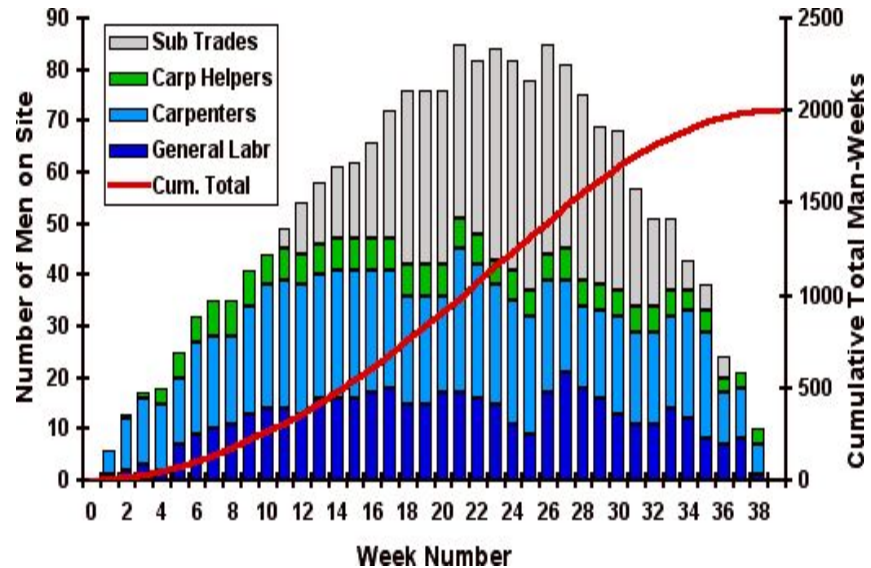

Fig 1. Daily man power progress

\section{TIME DELAY ANALYSIS}

Delay is particularly original in building initiatives. Extend can also be prompted by the corporation, the Contractor, and the 0.33 party or the drive majeure that the parties to a contract cannot control. Prolong to completion of a challenge might bring tremendous losses on society as well because the mission fee.

It will accrue as a result of interior or external routine of the mission, it can be typical issues or man mistakes. Subsequently it influences on the project compilation time, it could be managed by way of taking preliminary precautions in proper method.

\begin{tabular}{|c|c|c|}
\hline $\mathrm{N}_{\mathrm{n}}$ & Causes of Delay & Gromp \\
\hline 1 & Original contract duration is ton short & Prnject \\
\hline 2 & Legal disputes $\mathrm{b} / \mathrm{w}$ various parties & Project \\
\hline 3 & Inadequate definition of substantial completion & Project \\
\hline 4 & Ineffective delay penalties & Project \\
\hline 5 & Type of construction contract (Turnkey, and etc.) & Project \\
\hline 6 & Type of project bidding and award (negotiation, lowest price, etc.) & Project \\
\hline 7 & Delay in progress payments by owner & Client \\
\hline 8 & Delay to furnish and deliver the site to the contractor by the owner & Client \\
\hline 9 & Change orders by owner during construction & Client \\
\hline 10 & Late in revising and approving design documents by owner & Client \\
\hline 11 & Delay in approving shop drawings and sample matcrials & Clicnt \\
\hline 12 & Poor communication and coordination by owner and other parties & Client \\
\hline 13 & Slowncss in decision making process by owner & Clicnt \\
\hline 14 & Conflicts between joint-ownership of the project & Client \\
\hline 15 & Unavailability of incentives for contractor & Client \\
\hline 16 & Suspension of work by owner & Client \\
\hline 17 & Difficulties in financing project by contractor & Contractor \\
\hline 18 & Conflicis in sub-conlacions schedule in execuion of project Cunls acios & Coniliacior \\
\hline 19 & Rework due to errors during construction & Contractor \\
\hline 20 & 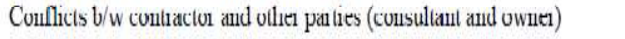 & Conilacior \\
\hline 21 & Poor site management and supervision by contractor & Contractor \\
\hline 22 & Poor communication and coordination by contractor with other parties & Contractor \\
\hline 23 & Ineffective planning and scheduling of project by contractor & Contractor \\
\hline 24 & Improper construction methods implemented by contractor & Contractor \\
\hline 25 & Delays in sub-contractors work & Contractor \\
\hline 26 & Inadequate contractor's work & Contractor \\
\hline 27 & Frequent change of sub-contractors because of their inefficient work & Contractor \\
\hline 28 & Poor qualification of the contractor's technical staff & Contractor \\
\hline 29 & Delay in site mobilization & Contractor \\
\hline
\end{tabular}

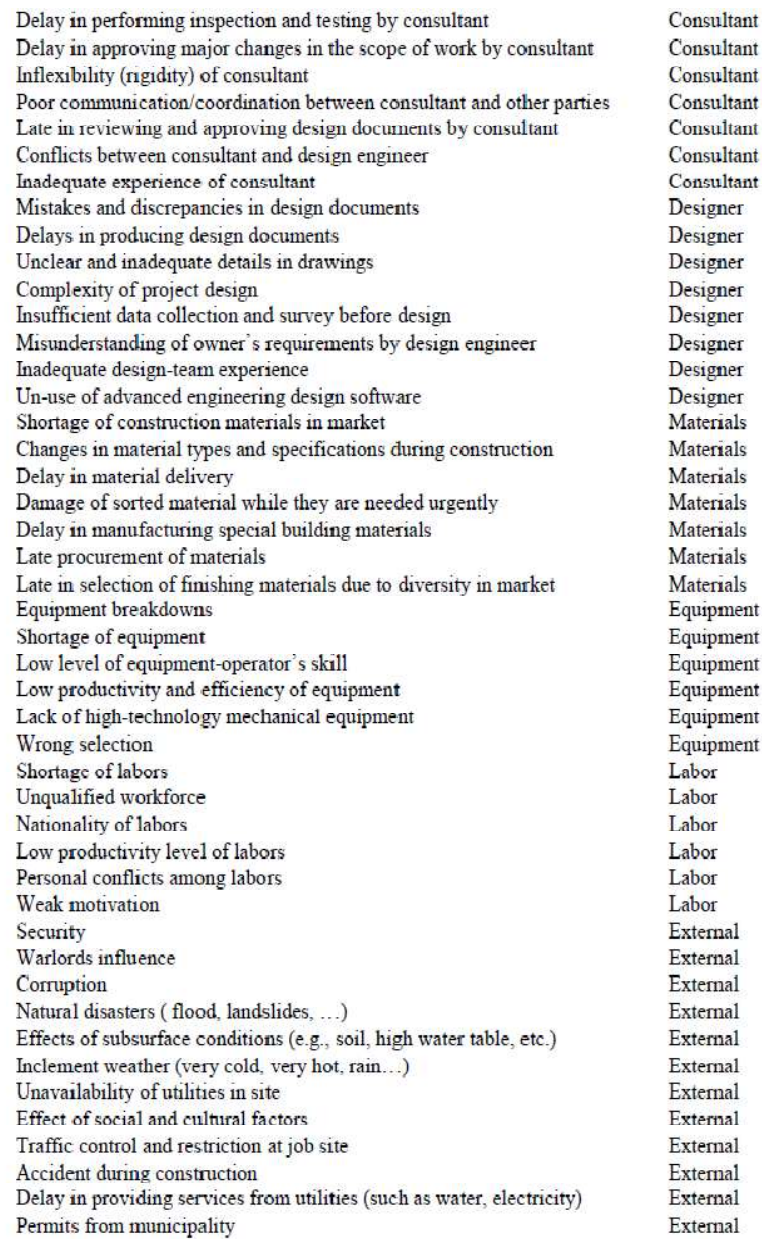

External

\subsection{Reasons for the Delay}

A development challenge time table may just mean distinct matters to the designers, contractors, sub-contractors, suppliers and the house owners concerned within the construction approach. The schedule may imply the completion date required for section of the work. The agenda may just imply the agenda values the contractors put up against which month-to-month progress payments will likely be made. The agenda might also confer with the procedure of sequencing and phasing individual activities required to complete the challenge. In this file construction time table way a graphical presentation, which shows the phasing expense of development events with the opening and completion dates are sequential relationship among the many various pursuits in a undertaking in order that the work may also be carried out in an orderly and strong method.

- Estimation of time required to carry out every community endeavor.

- Making use of these time estimates, compute the time period required for overall task completion.

- Estimate time intervals inside which each undertaking ought to begin and finish satisfying the completion date requirement.

- Estimation of portions of labor for each and every of the factor endeavor involved.

- Identify these movements whose expedient execution is primary to well timed venture completion. 
- If the assignment completion date just isn't regular with contract or different necessities, shorten the project length as a minimum viable cost.

- Making use of the surplus of flow occasions that the majority events possess, alter the and conclude occasions of selected routine to cut back useful resource conflict and delicate out requires manpower and equipments.

- Make-up a work task time table this shows estimated calendar dates for the start and conclude of each endeavor.

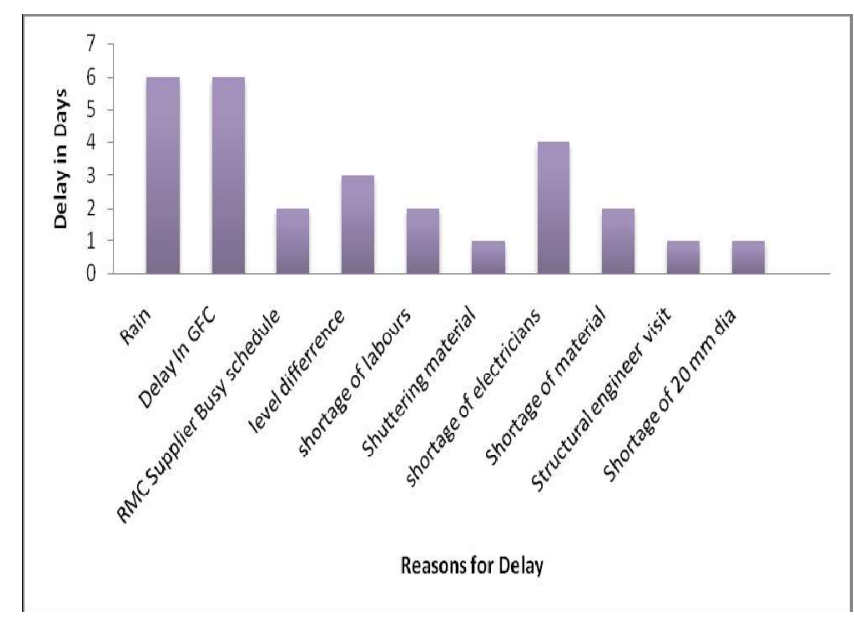

\subsection{Types of Schedules in MSP}

- Manual schedule

- $\quad$ Automatic schedule

\subsection{Tracking}

Monitoring is the process of gathering, getting into and analyzing of actual venture efficiency values, comparable to work on tasks and exact durations. Project monitoring refers back to the management of initiatives, which involves but will not be restrained to measuring and reporting the reputation of milestones, mission and events results. Undertaking monitoring might also seek advice from undertaking administration software, which automates the monitoring of assignment assignments, eve and pursuits regarding mission

A project is a one-time effort to accomplish an specific purpose with the aid of a designated time. Each and every undertaking is unique although similar venture may exit. Venture has a specific opening and a specific ending. Project has administration is the approach of overseeing planning organizing, scheduling, main, speaking and controlling of events to achieve the pre-outlined effect on time and within price range.

One of the crucial key components of task of assignment administration is controlling. By and large, the desires of element at which you need to track progress. In illustration, you can also monitor comfortably milestones to be certain that they have got been reached otherwise you would track the quantity of hours every resource as spent on a venture and the related fees. Undertaking tracking requires a cautious steadiness of monitoring to make sure that you will obtain the outcome and respond to any incidents or roadblocks, whilst averting micro management and decreasing team member's capacity to make selections.

Properly tracking exact work and comparing it's towards normal plan is valuable to identify the difference in specific and planned and it enables to adjust incomplete challenge of the plan.

\subsubsection{Daily Progress Reports}

The DPR consist of detail description of the work done, labor and resources required for the work and report of the inventory .All DPR from the starting day of project till now have been collected sample of DPR is given in appendix .

It is vitally primary to record each and every days Work and the assets used for activities; certainly these that are impacting the task agenda. This needs to be accomplished every day.

It's mostly worthy to enhance the file of events or circumstances with sketches, photographs, videotape recordings, or other ways.

On enormous projects, each and every Inspector assigned to a foremost operation have to maintain a separate normal daily progress record or diary. The PM and different key project personnel must document undertaking information, together with,

\section{ACTIVITIES WITH THEIR PLANNED DURATION}

Total activities for constriction of the project with their planned duration (Based on work output and man power available on site)are entered in MS project for further working.

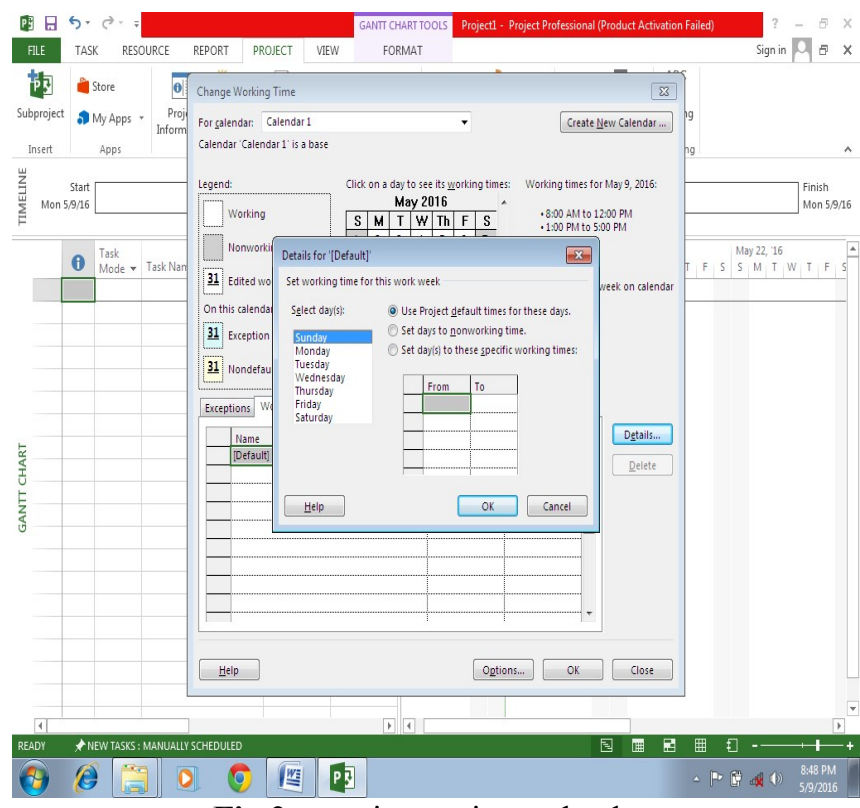

Fig 2 .creating project calendar 


\begin{tabular}{|c|c|c|c|c|c|c|c|c|}
\hline & (i) & Task Name & - Juration $\mathbf{v}$ & $\begin{array}{l}\text { Baseline } \\
\text { Start }\end{array}$ & $\begin{array}{l}\text { Baseline } \\
\text { Finish }\end{array}$ & Actual Start $\mathbf{V}$ & Actual Finish - & $\begin{array}{l}\% \\
\text { Actual }\end{array}$ \\
\hline 1 & & $\triangle \mathrm{MLCP}$ & 335 days & Thu 4/14/16 & Wed $7 / 26 / 17$ & Thu 4/14/16 & NA & $40 \%$ \\
\hline 2 & & $\triangleright$ Design Phase & 45 days & Thu 4/14/16 & Wed 6/15/16 & Thu 4/14/16 & NA & $51 \%$ \\
\hline 7 & & $\triangleright$ & 15 days & Thu 6/2:16 & Wed 6/22/16 & Thu $6 / 2 / 16$ & NA & $98 \%$ \\
\hline 14 & & Fabrication \& Site Mobilization of Steel Structures & 45 days & Thu 6/23/16 & Wed 8/24/16 & Thu 6/23/16 & NA & $41 \%$ \\
\hline 17 & & Construction Phase & 285 days & Thu 6/23/16 & Wed 7/26/17 & Thu 6/23/16 & MA & $39 \%$ \\
\hline 18 & & $\Delta$ Civil works & 165 days & Thu 6/23/16 & Wed 2/8/17 & Thu 6/23/16 & NA & $49 \%$ \\
\hline 19 & & $\triangleright$ Substructure & 57 days & Thu $6 / 23 / 16$ & Fri 9/9/16 & Thu $6 / 23 / 16$ & NA & $43 \%$ \\
\hline 28 & & $\triangle$ Super Structure & 110 days & Thu 9/8/16 & Wed 2/8/17 & Thu 9/8/16 & NA & $50 \%$ \\
\hline 29 & & $\Delta$ Ground Floor Roof & 35 days & Thu 9/8/16 & Wed 10/26/16 & Thu 9:8/16 & MA & $76 \%$ \\
\hline 30 & $\checkmark$ & Baseplate fabrication,Anchor Bolts,Steel Column Aligning \& Erection & 20 days & Thu 9/8/16 & Wed 10/5/16 & Thu 9/8/16 & Wed 10/5/16 & $100 \%$ \\
\hline 31 & & $\triangle$ Slab & 30 days & Thu 9/15/16 & Wed 10/26/16 & Thu 9/15/16 & NA & $66 \%$ \\
\hline 37 & & $\Delta$ First Floor Roof & 35 days & Thu 9/29/16 & Wed 11:16/16 & Thu 9/29:16 & IIA & $31 \%$ \\
\hline 38 & & Baseplate fabrication,Anchor Bolts,Steel Column Aligning \& Erection & 15 days & Thu 9/29/16 & Wed 10/19/16 & Thu 9/29/16 & NA & $53 \%$ \\
\hline 39 & & $\triangle$ Slab & 30 days & Thu 10/6/16 & Wed 11/16/16 & Thu $10 / 6 / 16$ & NA & $24 \%$ \\
\hline 45 & & $\triangle$ Second Floor Roof & 35 days & Thu 10:20/16 & Wed $127 / 16$ & Thu 10/20:16 & NA & $46 \%$ \\
\hline 46 & & Baseplate fabrication,Anchor Bolts, Steel Column Aligning \& Erection & 15 days & Thu 10/20/16 & Wed 11/9/16 & Thu 10/20/16 & NA & $67 \%$ \\
\hline 47 & & $\triangleright$ Slab & 30 days & Thu 10/27/16 & Wed 12/7/16 & Thu 10/27/16 & NA & $40 \%$ \\
\hline 53 & & $\Delta$ Third Floor Roof & 35 days & Thu 11/10/16 & Wed 12/28/16 & Thu 11/10/16 & MA & $47 \%$ \\
\hline 54 & & Baseplate fabrication,Anchor Bolts, Steel Column Aligning \& Erection & 12 days & Thu 11/10/16 & Fri 11/25/16 & Thu 11/10/16 & NA & $97 \%$ \\
\hline 55 & & Slab & 30 days & Thu 11/17/16 & Wed $12 / 28 / 16$ & Thu 11/17/16 & NA & $35 \%$ \\
\hline 61 & & $\triangle$ Fourth Floor Roof & 35 days & Thu 12/1/16 & Wed 1/18/17 & Thu 12/1/16 & MA & $49 \%$ \\
\hline 62 & $\checkmark$ & Baseplate fabrication,Anchor Bolts,Steel Column Aligning \& Erection & 12 days & Thu 12/1/16 & Fri 12/16/16 & Thu $12 / 1 / 16$ & Fri 12/16/16 & $100 \%$ \\
\hline 63 & & $\triangleright$ Slab & 30 days & Thu 12/8/16 & Wed 1/18/17 & Thu 12/8/16 & NA & $37 \%$ \\
\hline 69 & & $\triangle$ Fifth Floor Roof & 35 days & Thu 12/22/16 & Wed 2:8/17 & Thu 12/22/16 & IIA & $47 \%$ \\
\hline 70 & $\checkmark$ & Baseplate fabrication,Anchor Bolts, Steel Column Aligning \& Erection & 12 days & Thu $12 / 22 / 16$ & Fri 1/6/17 & Thu $12 / 22 / 16$ & Fri 1/6/17 & $100 \%$ \\
\hline 71 & & $\triangleright$ Slab & 30 days & Thu $12 / 29 / 16$ & Wed 2/8/17 & Thu 12/29/16 & NA & $35 \%$ \\
\hline 77 & & Finishing & 45 davs & Thu 2/2/17 & Wed 4/5/17 & Thu $2 / 2 / 17$ & NA & $19 \%$ \\
\hline
\end{tabular}

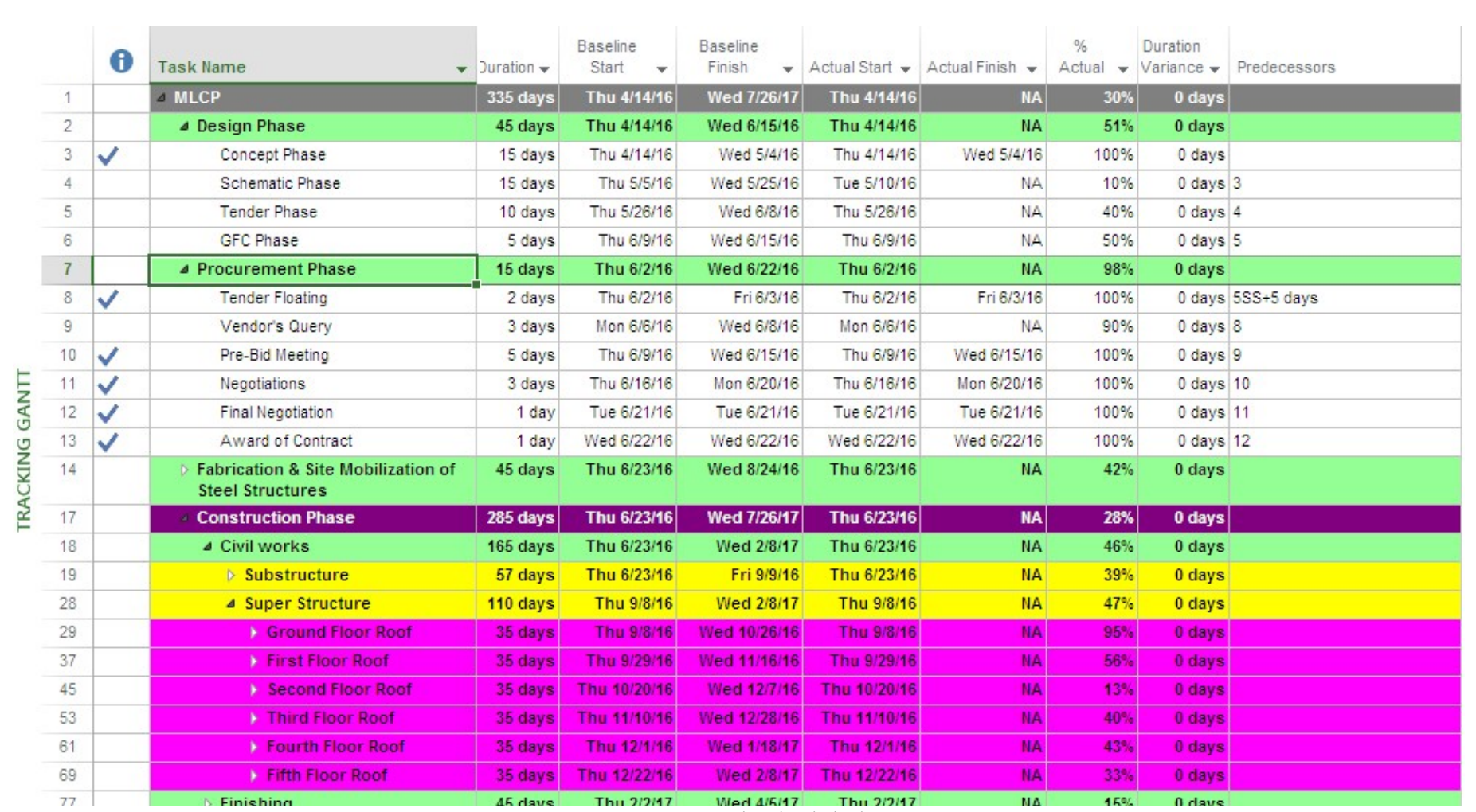

Fig 4. Actual scheduled

\section{CONCLUSION}

Discussions with other Project Managers of the Project Management Consultancy (PMC), clients and contractors indicate that Time Management as a discipline is not given high importance. This accounts for regular time and cost overruns in most projects with resultant dissatisfaction to the end user and losses to all stakeholders.
The following points are highlighted:

- Time Management principles as laid down by Project Management Body of Knowledge (PMBOK) are not rigorously followed.

- In this specific project there were many opportunities for catch up actions which have not been adopted.

- The Time Management practices are not used as a continuum from inception to change management covering 
risks and delays. Thus while the intent of the SOPs (Standard Operating Procedures) is to provide adequate control, it has not been implemented in practice.

Discrete implementation of the SOPs (Standard Operating Procedures) has resulted in loss of control. Project Planning is slowly being recognized as a separate discipline and is also being supported by a dedicated resource in most projects. However the act of planning is becoming a one man responsibility instead of involving all stakeholders in planning, review and re-planning. Such a concentrated effort from all stakeholders can ensure timely delivery of projects. So for the Project Implemented by me was delayed for $10 \%$ of total work.

\section{ACKNOWLEDGEMENTS}

I am thankful to Mr. Shashikumar A and Dr.GNarayana for their guidance. I also thank department of civil engineering S J C institute of technology, chickallapura. And last but not the least my dear friends who have supported me to complete this projet work.

\section{REFERENCES}

[1]. Abichou T. Benson, C. Edil T., 1998a.Database on beneficial reuse of foundry by- products. Recycled materials in geotechnical applications, Geotech. Spec. Publ.No.79, C. Vipulanandan and D.Elton, eds., ASCE, Reston, Va., 210223

[2]. Bemben,S.M.,Shulze,D.A.,1993.The influence of selected testing procedures on soil/geomembrane shear strength measurements.Proc.,Geosynthetics '93,Industrial Fabrics Association International,St.Paul,Minn.,619-631.

[3]. Bemben, S.M., Shulze, D.A., 1995.The influence of testing procedures on clay/geomembrane shear strength measurements. Proc. Geosynthetics '95, IFAI, St.Paul, Minn., 1043-1056.

[4]. Fredlund, D.G., Morgenstern, N.R., Widger, R.A., 1978.Shear strength of unsaturated soils.Can.Geotech.J.,Ottawa,15(3),313-321.

[5]. IS: 8112-1989, Specifications for 43-Grade Portland cement, Bureau of Indian Standards, New Delhi, India.

[6]. IS: 383-1970, Specifications for coarse and fine aggregates from natural sources for concrete, Bureau of Indian Standards, New Delhi, India.

[7]. IS: 10262-1982, Recommended guidelines for concrete mix design, Bureau of Indian Standards, New Delhi, India.

[8]. IS: 1199-1959, Indian standard methods of sampling and analysis of concrete, Bureau of Indian Standards, New Delhi, India.

[9]. IS: 516-1959, Indian standard code of practice- methods of test for strength of concrete, Bureau of Indian Standards, New Delhi, India.

[10]. Javed, S., Lovell, C., 1994.Use of Waste foundry sand in Highway construction. Rep. JHRP/INDOT/FHWA94/2J, Final REP., Purdue School of Engg., West Lafayette, Ind.

\section{BIOGRAPHIES}

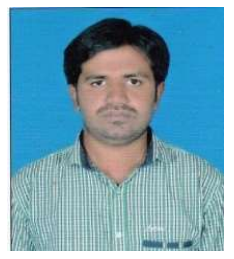

VIjayendra B V, Pursuing Final Year Mtech in Infrastructure Engineering and managemnt in SJC institute of Technology, Chickballapur. vijayendrabvgowda@gmail.com $\mathbf{9 5 9 1 9 6 8 7 6 1}$

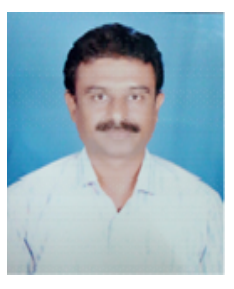

Mr.Shashi Kumar. A, Assistant Professor, Department of Civil Engineering, SJC institute of Technology, Chickballapur. He has wide experience in teaching field for over 15 years and currently pursuing his Ph.D. Ask0084@gmail.com

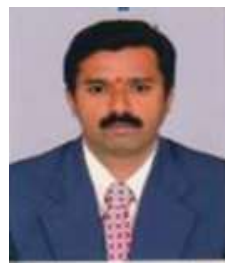

Dr.G.Narayana, Professor and Head of Civil Engineering Department, SJC institute of Technology, Chickballapur, have a wide experience in teaching and research in Structural Engineering field. $\mathrm{He}$ is also a Structural Designer and Consultant formany Projects. narayanag@rediffmail.com 